\title{
Theriac and Tao: More Aspects on Byzantine Diplomatic Gifts to Tang China
}

\author{
Vicente Dobroruka \\ University of Brasilia, Brasília, Brazil
}

\begin{abstract}
This article deals with the presenting of diplomatic gifts around the 7th Century from the Roman Empire in the East (i.e. the Byzantine Empire), and among these a kind of medication supposedly capable of curing all sorts of illnesses, theriac. The links between these uses and Taoist expectations regarding ever-lasting life are discussed herein in the context of that diplomatic mission. It explores the different understandings of what theriac meant in the Byzantine and in the Tang courts. This sheds light on the kind of different misunderstandings, sometimes of an ironical nature, which may happen in intercultural contacts of political-diplomatic nature.
\end{abstract}

Keywords: medieval and ancient medicine, Byzantine diplomacy, Taoism during the Tang period

\section{Introduction}

Since Antiquity, the search for medicine that may provide a better life, a longer one ore ven the cure af various diseases has been a constant, at least in tha Greek-Hellenized world (which incidentally inludes Rome). In the 7th Century, where information regarding Byzantine political and social issues is almost entirely lacking (a situation that would last almost until the end of the 8th Century, for our purposes), the amount of information regarding this diplomatic mission gives us is priceless.

While some sources assume that not only the effects but the very origin of theriac is shrouded in discredit, I think that others are correct in ascribing it to the researches of Mithridates VI, king of Pontus (134-63 B.C.), obsessed as he was with poisons and plants.

This paper is not devoted to that specific theme (for that I should direct the reader to more closely related bibliography ${ }^{1}$ ) but only to the cultural understanding of what Byzantines intended to present as a gift to a Chinese court, as a chemical capable of enhancing or prolonging life, in a political milieu familiar with the concept but which had a wholly different approach to it. The origins of that gift may be ascribed to the court of Mithridates.

In 667, ambassadors from "Rum" (i.e. from the Byzantine Empire, who called themselves) presented the emperor Gaozong, of the Tang Dynasty, in China, with theriac. It was then thought that it contained the gall of swine, was dark red in colour and that the Western diplomats held it in great esteem. The pharmacologist $\mathrm{Su}$ Kung (Tang period) wrote that it had proved its effectiveness against "the hundred ailments". If this

\footnotetext{
Vicente Dobroruka, MSt, DPhil, Oxford, Life Member of Clare Hall, Cambridge, Life Member of the Ancient India and Iran Trust, Cambridge, Member of the Societas Iranologica Europeaea, Ancient History Fellow at the University of Brasilia.

${ }^{1}$ See, as a recent, readable and scholarly well-researched Mayor (2010).
} 
remedy-cum-gift comprised ingredients such as opium, myrrh, and hemp, we do not know.

In short, how are we to understand the cultural exchange of a product of Greek or Hellenistic origin in terms of Chinese reception, use and understanding of its provenance?

\section{The Nature and Importance of Theriac in Antiquity}

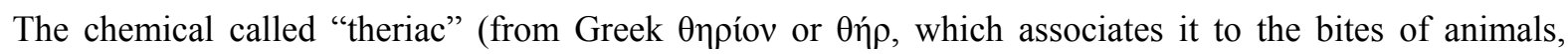
especially wild ones) became especially popular after its diffusion by Galen, who wrote a treatise on it (Theriake); that was in the beginning of the Second Century CE. But previous variants of it can be traced to Theophrastus (on his treatise on plants) ${ }^{2}$ and to Nicandros of Colophon ${ }^{3}$ who corresponded with Mithridates VI Eupator and may have given him receipes or suggestions. ${ }^{4}$

It is important to note that poisoning was a most-feared threat in Hellenistic-Roman Antiquity (see, e.g. the fear Nero had of being poisoned, the version of "theriac" prepared by his own physician and the many poisonings at Mithridates' own court—although the galene taken by Nero seemed to be a sort of tranquilizer that possibly vitiated the user, and bears no relation to the name of Galen). ${ }^{5}$

The preparation of the "universal" antidote, even before Galen, became more and more exotic, with implications on its functionality. ${ }^{6}$ It appears that the further we move from the more ancient formulae, the less effective and more bizarre the receipes become.

Mithridatum, the "original" theriac, failed against many diseases under several different testing conditions - this did happen against black death and epilepsy (Norton, 2006, p. 63). It also seems that as centuries passed, the anti-inflammatory ingredients became less frequent in the formulae, thus diminishing the efficiency of bio-active ingredients (one must also bear in mind how inconclusive ancient evidence can be) (Norton, 2006, p. 64). Theophastus' original receipe may very well work as an efficient anti-inflammatory (Norton, 2006, pp. 64-65). ${ }^{7}$

Examples of how complex and somewhat mystified by "Oriental" components these potions became exemplified by Pliny, in his Natural History, 29.1:

\footnotetext{
${ }^{2}$ I used the following edition for Theophrastus_Enquiry into Plants. Books I-V. New York: Loeb Classical Library, 1976. Vols. $1-2$.

${ }^{3}$ Nicander of Colophon may have worked with Attalus III of Pergamon (ca. 170 BC-133 BC), also famous for his toxicological experiments in the library of Alexandria. Cf. Mayor, op.cit. Since I used an e-book, I can only give the highlight and section as they appeared on a Kindle device, but a simple "search" would get the reader to the point. In this case, we are at Loc.2889, note 27 - cf. Strabo, Geography 12.3; 11.14; on toxic minerals, cf. Pliny's Natural History 33.31-36; 35.13-15; 34.55-56; and again Theophastus On Stones 8.48-60.

${ }^{4}$ Mayor, op.cit. "Traditionally, theriacs combined substances thought to counter poisons. Some common ingredients were cinnamon, myrrh, cassia, honey, castor musk from beaver testicles, frankincense, rue, tannin, garlic, Lemnian earth, Chian wine, charcoal, curdled milk, centaury, aristolochia (birth wort), ginger, iris (orris root), rue [sic], Eupatorium, rhubarb from the Volga, Hypericum (Saint-John's wort), saffron, walnuts, figs, parsley, acacia, carrot, cardamom, anise, opium, and other ingredients from the Mediterranean and Black Sea, Arabia, North Africa, Eurasia, and India. Modern science reveals that some of these substances can counteract illness and toxins". Loc.2867. The accurate properties of these substances will be discussed below. Cf. also Lenaus, Mithridates' secretary and who might have known the recipe of his theriac: Appian, Mithridatic Wars 30, Strabo, Geography 13.1; Suetonius, Grammarians 15, all quoted in Mayor, loc.4826.

${ }_{5}$ Guido Majno. The Healing Hand. Man and Wound in the Ancient World. Cambridge, MA/London: Harvard University Press, 1975, p. 415.

${ }^{6}$ The best work on the subject appears to be the article by Strata Norton. "The pharmacology of Mithridatum: a 2000-year-old remedy" in: Molecular Interventions 6:60-66, 2006; cf. also Annette I. Bierman. "Medical fiction and pharmaceutical facts about Theriac" in: Pharmaceutical Historian 24. 3:5-8, 1994.

${ }^{7}$ For a full table crossing ingredients versus their active components, cf. Norton, op.cit. pp. 62-63.
} 
"excogitata compositio luxuriæ". It was made of six hundred, i. e., a great many, different ingredients. The same author (XX, 24 (100), 264) has preserved a recipe of the theriac used by Antiochus the Great as an antidote against all poisons excepting that of the viper. It contained no gall, it is true, but it states that the medicine was made into pills of a certain weight ("pastillos victoriati ponderis"). Another recipe will be found in Pliny (XXIX, 4 (21), 70), in which theriac is also made into pills. From later accounts it appears that the composition of the drug varied at different times, and it looks as if the essential point in the matter is, that it was at any time a very complicated, expensive, and fashionable medicine. Pliny (XXIX, 1 (8), 25) seems to consider it an ostentatious humbug, and the Chinese may have been right in not giving it a more prominent place in their materia medica. ${ }^{8}$

But exotic as it may have become, any form of theriac was greatly appreciated - it was expensive, had an aura of secrecy and sophistication; the ideal gift among the exotic paraphernalia of diplomatic missions in Antiquity and the Middle Ages.

Thus theriac, in any of its guises, would, in principle, make the perfect diplomatic gift for any mission going to China: After all, Taoism had a long-standing tradition of alchemical pursuit of longevity potions (some of these with harmful rather than health-enhancing effects). But the role played by theriac in the diplomatic history of Chinese-Western powers relations would indeed be minimal, and follow a different path.

\section{Other Means by Which Theriac Had Reached China}

In a Chinese medical compilation, the Huihui Yaofang (Ming or Yuan; "huihui" is Chinese for "Islamic", or currently for Chinese Muslims - 回回), many hands can be seen on the mss. including several hands for Arabic and Persian for "theriac" (diyejia).

In the entry for diyejia we read:

Theriac (diyejia): Flavor: pungent, bitter, level, without poison. Treats the hundred illnesses, sudden diseases that would otherwise be fatal (zhong'e), the negative qi of kewu sickness [in children], and abdominal obstructions. It comes from the Western tribes (xirong). New addendum: It is said that [diyejia] is made of gall. Its appearance is like long spoilt pills, red-black in color. Foreigners (huren) occasionally bring it here, and it is extremely valuable. Experiments have shown it to be effective $[\ldots]{ }^{9}$

Now, this is by no means the first reference to diyejia; the first one comes in a Chinese medical text from 663 $\mathrm{CE}$, the Xinxiu bencao. ${ }^{10}$ Theriac entered China via India and Islam (in Islamic medicine it was already part of the canon in the Seventh Century, via Paulus of Aegina, one of the first links between Greek and Islamic medicine (via the Persian alchemist and physician al-Razi, 865-930 approx.) (Nappi, 2009, p. 746).

I am concerned, however, not so much about the pharmacological efficiency of theriac as such but about the role it may have played as an important part of diplomatic etiquette in Byzantine missions.

In this sense, it is somehow telling that references to it are altogether absent in Constantine Pophyrogenitus'

\footnotetext{
${ }^{8}$ Quoted by Friedrich Hirth. China and the Roman Orient. Researches into their Ancient and Medieval Relations as Represented in Old Chinese Records. Chicago: ARES Publishers, 1975, pp. 224-225.

9 Carla Nappi. "Bolatu's pharmacy: Theriac in early modern China" in: Early Science and Medicine, May 2009. p. 746. Bolatu is a Chinese transliteration for Plato, and thus a pun intended by the author on Plato's Pharmacy by Jacques Derrida (1972). I am extremely grateful to Dr. Nappi for giving me access to her own material. Cf. also Paul D. Buell. "How did Persian and other Western medical knowledge move East, and Chinese West? A look at the role of Rashīd al-Dīn and others" in: Asian Medicine 3, 2007, pp. 241-264.

${ }^{10}$ Bencao is the name given to a medical compilation.
} 
De administrando imperio ${ }^{11}$. Either due to the distances involved, to the lack of importance of Tang China in the general picture of Byzantine diplomacy, or to a mixture of both, etiquette and by extension theriac was not a priority in political dealings with a land most given to pharmacological experiments and especially to long-life elixirs.

As is well known, many of the T'ang emperors ate Taoist immortality elixirs, and some opinions held that their deaths from undiagnosed illnesses were actually due to poisoning by such potions [...] Drugs came from abroad by ordinary commercial routes as well and, of course, by the quasi-commercial diplomatic missions carrying token 'tribute' from distant princes to Ch'ang-an. These imported goods were strictly inspected at the frontier, and their sale price fixed according to their value and the requirements of Chinese policy. ${ }^{12}$ (Schafer, 1963, pp. 182-183)

However, we cannot be sure whether the panacea presented to the Chinese contained toxic ingredients like opium or hemp (Huard \& Wong, 1958, p. 205) ${ }^{13}$.

Nonetheless, Schafer quotes Chinese sources that are unanimous (although not always clearly stated) regarding the origins, contents and effects of the diplomatic gift: it came from "Rum", the country mentioned at the beginning of this paper, and in our case, in the year $667 \mathrm{CE}$.

Su Kung noted down that it had proved its usefulness against "the hundred ailments" [Quoted in Li Shieh-chen. Pen ts'ao kang mu. 50b; 24b]. (Schafer, 1963, p. 184)

In $667 \mathrm{CE}$, the term "Rum" could not possibly refer to the Sultanate of that same name, which prospered as an independent state in Anatolia only between 1077-1307 CE; but it should be noted that the Byzantines called themselves pouaío, and by extension, the Byzantine Empire was, in the eyes of neighbors, foes or allies often called simply "Rome". ${ }^{14}$ During the Seventh Century CE, the Byzantines' identity was still strongly rooted in Romanship, not until the Eleventh Century did any "rival" conception of Greek identity arise (Browning, 1992. p. xiii).

But the fact that the very term "Byzantine" was in itself derogarory when first coined by the Roman-admiring men of the Enlightenment does not suffice to prove that this embassy did come from a ruler from Constantinople; to have this proved we should turn to other kinds of evidence than Schafer's quick reference in his all-encompassing work on Tang exotics.

\section{Identification of Fu-lin as "Rum”}

Theriac was a commodity present in the embassy of $667 \mathrm{CE}$, whose nature we shall discuss below. In Chinese illustrations, theriac is presented as being offered by a foreigner kneeling; ${ }^{15}$ the subsequent implications of that are to be found in "Foreign Commodity Adapted to Chinese Pharmacopaea", below.

\footnotetext{
${ }^{11}$ Cf. Constantine Porphyrogenitus. De administrando imperio. Greek text edited by Gyula Moravcsik/English translation by Romilly J. H. Jenkins. Washington: Dumbarton Oaks Texts, 1967.

${ }_{12}$ Edward H. Schafer. The Golden Peaches of Samarkand. A Study of T'ang Exotics. Berkeley/Los Angeles/London: University of California Press, 1963, pp. 182-183.

${ }^{13}$ Pierre Huard and Ming Wong. "Structure de la medicine chinoise" in: Bulletin de la Societé des Études Indochinoises. Saigon, 1957 e Évolution de la matière médicale chinoise. Leiden: Brill, 1958, p. 205.

14 "The Byzantines did not call themselves Byzantines, but Romaioi-Romans. They were well aware of their role as heirs of the Roman Empire, which for many centuries had united under a single government the whole Mediterranean world and much that was outside it”. Cf. Robert Browning. The Byzantine Empire. Washington: Catholic University of America Press, 1992, p. xiii.

${ }^{15}$ Cf. Teruko Nakamura and Jiro Endo. "Introduction of theriac into China" in: Nihon Isshigaku Zasshi (Journal of Japanese History of Medicine), 46, 2000, pp. 358-359.
} 
That Ti-yeh-ka is the same as "theriac" has been proved long ago in Hirth's investigations; d'Herbelot suggests that this was a way to consume opium in disguise among Islamic peoples. ${ }^{16}$ Yet, although Islamic pharmaceutical benk, to which d'Herbelot refers, has a long history in the Oriental pharmacopaea, it comes from the Persian world.

It should be noted, however, that the Persian terms bang, banj or mang only came to be used as a reference including hemp after the Arab conquest, possibly in the 12th century: according to Belardi, in the book of Artay Viraz this virtually excludes the possibility that the seer is mixing wine with hemp ${ }^{17}$. (Dobroruka, 1979. p. 10)

The visionary in question should be using rather henbane, and here Hirth seems to lose track and confuse hemp, henbane, and opium (and even worse, theriac as a medium for it; that the formulae for theriac have changed as time passed is well demonstrated (see "The Nature and Importance of Theriac in Antiquity", above), but that it was consumed as a disguise for opium generally is something yet to be proved).

Another issue to be taken into account is that China, in Byzantine mentality, was for long not more than the source of silk, important for official vestments, even though Byzantium itself could produce silk, neither in quality nor in quantity to be compared to Chinese silk. Procopius quotes an Indian embassy to Justinian, whose representatives explained to the emperor that silk was made in "Serinda", supposedly in the north of India (Gothic War, 8.17) ${ }^{18}$.

But contacts between East and West, however, futile any attempts at a common, grand strategy between Byzantium and China might have been from the start, given the distances implied, could be more common than we think. In Shanxi, in 1953, a solidus from the time of Emperor Justin II was found in a tomb of the Sui period. It could well be that Chinese-Byzantine diplomacy became an "empty exchange of courtesies", but nonetheless, it remained active until the very last years of the Byzantine Empire. ${ }^{19}$

Now, Chinese references to an embassy in 667 CE refer to it coming from "Fu-lin". This poses something of a problem that Hirth addressed successfully in an old but still useful work. ${ }^{20}$

Yüan-chuang's work, the Ta-t'ang-his-yü-chi, which was completed in A.D. 646, contains a similar mention, but the name is there ${ }^{21}$ written 彿檩國 Fu-lin-kuo. I may add that this lin 檩 is identical in sound with lin 林. The old

\footnotetext{
${ }^{16}$ Cf. Barthélemy d'Herbelot. Bibliotheque orientale, ou Dictionaire universel contenant generalement tout ce qui regarde la connoissance des peuples de l'Orient. Paris: Compagnie des Libraires, 1697, Vol. III, p. 453. "Ceux qui usent ordinairement du Benk et de l'Afioun [=Opium], sont nommez par les Arabes, Persans et Turcs Benghi, et Afiúni, et passent parmi eux pour des débauchez: car ces deux drogues qui ôtent la liberté de l'esprit et l'usage de la raison, produisent le même effet que le vin, sont condamnées par les Docteurs Musulmans les plus rigides, quoy qu'il n'en soit fait aucune mention dans l'Alcoran; et parce que la Theriaque quoyque permise, prête souvent son nom à ces deux drogues, le nom de Theriaki ou preneur de Theriaque, s'applique aussi à un débauché”.

${ }_{17}$ Vicente Dobroruka. "Chemically-induced visions in the Fourth Book of Ezra in light of comparative Persian material" in: Jewish Studies Quarterly. Vol. 13.1. Princeton: Mohr Siebeck, 2006 and Walter Belardi. The Pahlavi Book of the Righteous Viraz. Rome: University Department of Linguistics and Italo-Iranian Cultural Centre, 1979, p. 10.

${ }^{18}$ Edward N. Luttwak. The Grand Strategy of the Byzantine Empire. Cambridge, MA/London: Harvard University Press, 2009, pp. 168-169.

19 An example of such courtesies remained the communiqué in 1372 that Hongwu, the first Ming emperor, sent to John V Palaeologus - without knowing how much had remained of the former Byzantine empire. Cf. Kuttwak, op.cit. p. 169.

${ }^{20}$ Hirth, op.cit. (location imprecise since I used a Word electronic edition; as in other cases, a "search" should yield the desired results).

21 As Hirth notes: "Ch. XI, p. 23. The Yen-pao-tan-yü, quoted in the Ko-chih-ching-yüan, ch. 33, p. 31, has preserved under the name of Fo-lin an account which I have no doubt refers to our Fu-lin. It says that 'when the ambassadors from Fo-lin came to court [the embassy referred to arrived during the period Ching-yu = A.D. 1034 to 1038, as I conclude from K'ang-hsi's quotation of the same passage], they stated that this state at the time had ceased to exist. Its territory was very extensive; that it was under seventy-two leaders (chiu-chang); there was in the country a 'quicksilver-sea' with a circuit of about 40 or 50 li', etc., etc. I shall refrain from quoting the account of the manner of obtaining the quicksilver, occupying about half a page in the Ko-chih-ching-yüan, as it apparently throws no light on the subject. The Ko-chih-ching-yüan, ch. 35, p. 19, has a quotation from the same work (Yen-pao-tan-yü) in connection with Fu-lin coins, apparently a transcript of the passage N16; and there the name appears as Fu-lin".
} 
sound of the two characters fu and lin 彿檩 was most probably not po-lin, as those who wish to refer it to the Greek $\pi$ ó $\lambda \imath v$ would like to make it; nor fu-lan, which would suit the defenders of the "Frank" etymology.

What is more, Hirth adds that

The siege of the capital of Fu-lin, as mentioned in the Chiu-t'ang-shu (K 35) and in the Hsin-t'ang-shu (L 42 and 43) is described in a text narrating certain historical facts in a chronological series. In the first-named work, the facts stated appear in the following order:

1. The emperor Yang-ti wishes to communicate with Fu-lin, A.D. 605-617, (K33).

2. An embassy is sent to China in A.D. 643 (K34).

3. The capital of Fu-lin is besieged by the Arabs, and finally submits to Arab rule (K35).

4. An embassy is sent to China in A.D. 667 (K36).

5. An embassy is sent in A.D. 701 (K37).

6. An embassy is sent in A.D. 719 (K38).

Although no date is mentioned in connection with the siege of the Fu-lin capital, the strictly chronological order in which these facts are enumerated in the T'ang annals, clearly shows that the event referred to must have taken place previous to A.D. 667 . (1975, pp. 51, 72, 113)

In short, Hirth's reasoning implies that the embassy of $667 \mathrm{CE}$ should have been sent before the first siege of Constantinople by the Arabs, in $674 \mathrm{CE}$, and its sender must have been the ruler of Persia, Syria and Egypt. However, T'ang annals may have confused the origin of the embassy, even if Hirth's reasoning is, in my opinion, a most correct one.

\section{Foreign Commodity Adapted to Chinese Pharmacopaea}

Turning back to theriac itself, it was held in great esteem for the reasons already given but possibly also as a true medicine for the times: tiyriaq (تِرئيق) was quoted even by al-Bīrūnī (973?-1048) in his medical canon. ${ }^{22}$ But considering several factors, the submissive position of the foreigners presenting it to the Chinese, the long-standing tradition of its use, the frontier difficulties alluded to by Schafer and others, how come that theriac was included and had a long future in Chinese pharmacopaea?

One easy explanation is that, accustomed as they were to life-enhancing or even eternal-life promising elixirs as the Chinese were, theriac was just another item to be included in their arsenal of such drugs.

However, it appears more reasonable to suppose that the understanding of "theriac" became, in Chinese terms, that it was an animal product and not such a complex mixture. This enabled it to be put under the "control" and understanding of Chinese doctors and meant that, although an import, it was not better than Chinese remedies. In many Chinese encyclopaedias we can see diyejia being given by a foreigner kneeling down to a Chinese, thus bringing his product from a submissive point of view. ${ }^{23}$

\section{Theriac and Taoism: A Hiatus}

We can close this paper by offering a glimpse at something that is somewhat surprising to see during the Tang period, with all the retrospective history of Taoist alchemy and its obsession with life-enhancing or eternal life potions, how theriac was to be understood as something entirely different, and even more how it as

${ }^{22}$ Hakim M. Said. Al-Biruni's Book on Pharmacy and Materia Medica. Karachi: Hamdard Foundation, 1973.

${ }^{23}$ Nappi, op.cit. p. 753. 
introduced and accepted into Chinese pharmacopaea.

While Western worries about poisoning were the chief concern regarding the utility of theriac, Chinese alchemy, strongly linked to Taoism (possibly even earlier than Lao-Tse or Chuang-Tse times, or legendary lifetimes), was mostly concerned with life-enhacing or prolonging potions. ${ }^{24}$ These go way back to Antiquity times, when the first cultural exchanges regarding alchemy were made between the West and China ("A large portion of the Chinese trade, both by land and sea routes, passed through Alexandria" (Obed, 1928, p. 117) ${ }^{25}$ ).

Ano on the other side of the road (literally), and at the very same time of the $667 \mathrm{CE}$ embassy, the following exchange was taking place:

[...] a Chinese Emperor of the T'ang dynasty senta n envoy, Wang Hsüan-ts'e, to India between AD 643 and 665 [...] He was a specialist in prolonging life - that is to say, an alchemist - and a noted magician. He brought back with him an Indian Brahmin, Narayamasvamin, who was an alchemist and physician, while another magician came over from Kashmir in 664-5 on the orders of the Emperor Kao Tsung: this magician was thought to have possessed the drug of longevity. $^{26}$

One way of explaining this two-way route and at the same time the incorporation of theriac into Chinese pharmacopea is due to the fact that, no matter what the real origins and procedures of the 667 mission were, theriac, rather, tiyriaq, or Ti-yeh-ka, was already familiar to the Chinese via Indian and Islamic trade. This way, the bombastic affirmation that theriac may have been the first form of opium-consuming in China becomes far less important when put into context: The Chinese were already familiar with far more potent "life-enhancing" potions which were little more than poisons.

Opium would be far less harmful and we must still take into account whether Ti-yeh-ka truly had opium among its ingredients or not.

\section{Conclusion}

In the form that it reached China, theriac was a remedy with a long history behind it; this development meant that we do not have enough evidence to prove whether it worked or not. What can be proved in terms of pharmaceutical history is that theriac apparently lost its efficiency as its ingredients were changed from the initial, commonsensical ones to more exotic, on one hand, or to more readily available on the other.

Theriac also reached Tang China via other routes, some of them well-known (trade with Arabs and India); this was mentioned above and may be the chief reason why Ti-yeh-ka failed to make the impact one should expect in a society used to similar drugs when theriac was brought by the 667 embassy.

In short, the $667 \mathrm{CE}$ mission took Ti-yeh-ka to Tang China, where it was first taken for granted as a sort of panacea (contrast this with the Western almost obsession with poisoning, beginning with Mithridates); then it was gradually understood in Chinese medicine's own terms and was thus incorporated into Tang pharmacopeia. The fame theriac was to enjoy, for good or bad, in the Western world in the next thousand years or so took a very different form in Chinese medical treatises, where Ti-yeh-ka was quickly made part of the traditional pharmacopaea.

\footnotetext{
${ }^{24}$ Jean C. Cooper. Chinese Alchemy: The Taoist Quest for Immortality. New York: Sterling, 1990, p. 1.

25 Obed S. Johnson. A Study of Chinese Alchemy. Shanghai: Commercial Press, 1928, p. 117.

${ }^{26}$ Cooper, op.cit. p. 18. In some cases, the lethality of these elixirs may have been a deliberate form of suicide and, thus, of joining the Taoist "immortals"; cf. Cooper, op.cit. p. 55.
} 


\section{References}

Bierman, A. I. (1994). Medical fiction and pharmaceutical facts about theriac. Pharmaceutical Historian, 24(3), 5-8.

Browning, R. (1992). The Byzantine Empire. Washington: Catholic University of America Press.

Constantine Porphyrogenitus. (1967). De administrando imperio (On the adminstration of the Empire). (Greek text edited by Gyula Moravcsik / English translation by Romilly J. H. Jenkins). Washington: Dumbarton Oaks Texts.

Cooper, J. C. (1990). Chinese alchemy: The Taoist quest for immortality. New York: Sterling.

d'Herbelot, B. (1697). Bibliotheque orientale, ou Dictionaire universel contenant generalement tout ce qui regarde la connoissance des peuples de l'Orient (Vol.III) (Universal dictionary containg most matters regarding knowledge on Oriental peoples). Paris: Compagnie des Libraires.

Dobroruka, V. (2006). Chemically-induced visions in the Fourth Book of Ezra in light of comparative Persian material. Jewish Studies Quarterly, 13(1). Princeton: Mohr Siebeck.

Hirth, F. (1975). China and the Roman Orient. Researches into their ancient and medieval relations as represented in old Chinese records. Chicago: ARES Publishers.

Huard, P., \& Wong, M. (1957). Structure de la medicine chinoise (Structure of Chinese medicine). Bulletin de la Societé des Études Indochinoises. Saigon.

Huard, P., \& Wong, M. (1958). Évolution de la matière médicale chinoise (Evolution of Chinese medicine). Leiden: Brill.

Johnson, O. S. (1928). A study of Chinese alchemy. Shanghai: Commercial Press.

Luttwak, E. N. (2009). The grand strategy of the Byzantine Empire. Cambridge, MA/London: Harvard University Press.

Majno, G. (1975). The healing hand. Man and wound in the ancient world. Cambridge, MA/London: Harvard University Press, 1975.

Mayor, A. (2010). The poison king: The life and legend of Mithradates, Rome's deadliest enemy. Princeton: Princeton University Press.

Nakamura, T., \& Endo, J. (2000). Introduction of theriac into China. Nihon Isshigaku Zasshi (Journal of Japanese History of Medicine), 46.

Nappi, C. (2009). Bolatu's pharmacy: Theriac in early modern China. Early Science and Medicine, May 2009.

Norton, S. (2006). The pharmacology of Mithridatum: A 2000-year-old remedy. Molecular Interventions, 6, 60-66.

Said, H. M. (1973). Al-Biruni's book on pharmacy and materia medica. Karachi: Hamdard Foundation.

Schafer, E. H. (1963). The golden peaches of Samarkand. A study of T'ang exotics. Berkeley/Los Angeles/London: University of California Press.

Theophrastus. (1976). Enquiry into plants. Books I-V (Vols. 1-2). New York: Loeb Classical Library. 